V. I. PROKOPENKO ${ }^{1}$, Professor, Doctor of Engineering Sciences, prokopenko_vasil@ukr.net

P. I. PILOV ${ }^{1}$, Professor, Doctor of Engineering Sciences

A. Yu. CHEREP ${ }^{1}$, Associate Professor, Candidate of Engineering Sciences

D. P. PILOVA ${ }^{1}$, Associate Professor, Candidate of Economic Sciences

${ }^{1}$ Dnipro University of Technology, Dnipro, Ukraine

\title{
MANAGING MINING ENTERPRISE PRODUCTIVITY BY OPEN PIT RECONSTRUCTION
}

\section{Introduction}

The significant decline in output of machine-building products and mining and metals industry, respectively, are determined by the crisis phenomena in the economy of Ukraine. The market value of metallurgical raw materials is influenced in a great extent by its production capacities and supply volumes. Recently, considerable fluctuations in the volume of sales of manganese ore on the market led to changing of its price. According to S\&P Global Platts (China) [1], the market value of $44 \%$ of Manganese $(\mathrm{Mn})$ ore was US $\$ 6.70 /$ tonne, while the price for the $37 \%$ of $\mathrm{Mn}$ ore decreased to US $\$ 5.30 /$ tonne. The ore from Gabon (containing 44\% of $\mathrm{Mn}$ ) was offered for the price of US $\$ 5.80$ / tonne. In 2010, Ukraine imported manganese concentrate at a price of US $\$ 1320$ per ton. Today the price has dropped to US $\$ 910 /$ tonne [2]. In accordance with the selling price the enterprise's operating activity profit is formed. Hence if the enterprise is not able to compete in the market, its production volumes should be reduced.

In Ukraine the main domestic supplier of manganese concentrate to metallurgical plants is the Pokrovsky mining and processing enterprise (the Pokrovsky MPE). For the next years the changing of the demand for metallurgical raw materials supplied by the enterprise is considered on the basis of current volumes of product sales. There are sufficient industrial reserves of ore raw materials and labor resources at the enterprise in order to meet the demand. During 1989-2001 there was a remarkable decrease in the volume of produced concentrate. These volumes declined to a great extent in the period from 1990 to 1994 (from 4020 ktonnes/year to 1995 ktonnes/year). Subsequently, these volumes stabilized (Fig. 1). Although the Pokrovsky MPE's concentrate total production continued to decline. In 2002 it reached 1660 ktonnes/year.

During 2003-2007 the demand for manganese concentrate fell sharply in the market of metallurgical raw materials, and this led to a decline in annual output of this product to 820 thousand tons.

Production volume of higher grades' concentrates decreased by $10 \%$. Now the enterprise also produces a large volume of 2 nd grade products. Open pits supply manganese raw materials to processing plant according to the volume of mining that is needed to meet the demand of 380 ktonnes of concentrate per year.
Market conditions of the economic activity of Ukraine's mining and processing enterprises circumscribed the possibility of ore raw materials mining in acceptable earlier volumes, which led to the increase in the cost price and the decrease in the competitiveness of their products. This required the search for progressive approaches to the operation of mining-andtransport equipment and engineering solutions for the technology of deposit development. The of the technological scheme for the development of a horizontal deposit under the condition of roviding competitive cost for mining minerals are generalized in order to eliminate the incon-

The market demand for ore concentrate. This allows reducing production costs significantly, in particular transport costs, costs of over-

Key words: open pit mine reengineering, raw materials, technology of mining operations, , stripping method, productivity.

DOI: $10.17580 / \mathrm{em} .2020 .01 .08$

\section{Analysis of Recent Research and Publications}

Due to increased topicality of scientific and practical tasks of maintaining products' competitiveness of mining enterprises, in recent years more attention is paid to the substantiation of organizational and technical decisions and strategies for open pit mine reengineering under changing in demand for mined minerals [3], the productivity of mining enterprises for various options for the development of mining operations,

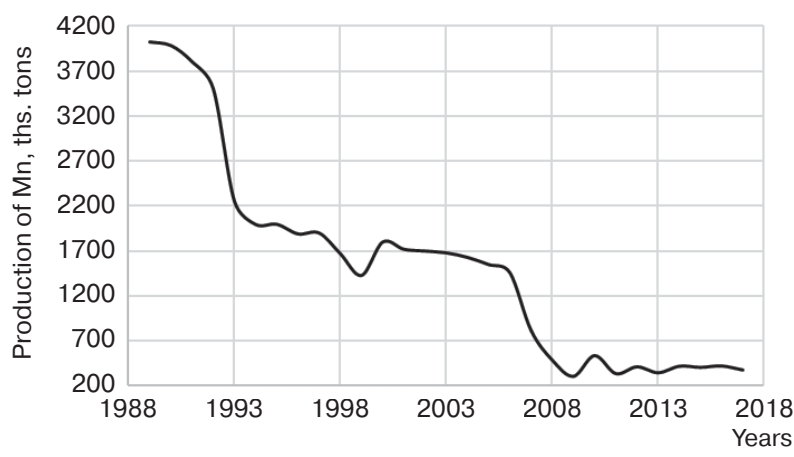

Fig. 1. Dynamics of manganese concentrate production at the Pokrovsky MPE 
which meets demand for mineral raw materials [4]. According to this aspect, the scenarios of changes in the market situation in the design and current planning of mining operations [5], conceptual provisions for determining the capacity and terms for cleaning-up of open pit fields [6] were considered. The importance of managing the volume of produced products by adapting the mining and processing enterprise to its changing demand was underlined by scientists $[7,8]$. The function of expenses form production volume was proposed. The task of planning the volume of extraction involves the procedure of deposit development by dividing it into several small segments or blocks, that maintains maximizing of the net present value of the operation [9]. In the article [10] modeling system based on the determination of probable terms of open pit closure and costs, is created. The system is grounded on the estimation of the time and cost of mining enterprise's closing in accordance with the chosen technology of deposit cleaning-up. The important question here is the more complete use of developed open pit's field, which contributes to a restoration of ecological and aesthetic state of a landscape [11].

\section{Aim}

Approaches for open pit mine reengineering, the technology and the organization of mining operations in a separate site or in the whole open pit, affect the production and capital costs, the intensity of the use of mining equipment, the loss of useful mineral, and, ultimately, the cost of its mining. This requires looking at the possibility of withdrawing the part of the funds and releasing an enterprise's funds, which were directed to servicing these funds and added to the production costs. Therefore, the purpose of this research is the synthesis of methodical approaches to the open pit mine reengineering in accordance with the reduced volumes of mining of minerals and on the basis of these approaches the improvement of the technological scheme and parameters of mining system of horizontal deposit that will provide competitive cost for mining minerals. Such open pit mine reengineering will involve some rebuilding of the technological complex of the open pit, which should meet the demand for ore raw materials and reduce its cost for the production of competitive concentrate.

\section{Presentation of the Main Material}

Open pit mine reengineering will be carried out by reconfiguration the mining complex on the basis of existing equipment that is not operated efficiently and can be moved from other sites or adjacent open pits. Due to a significant decrease in demand for products and output volumes, such a situation is common for Ukrainian enterprises of mining ore raw materials.

The parameters of the reengineering, its effectiveness is influenced by the existing parameters of the mining method and working size of the equipment, accepted in the operating technological complex. The length of the mining front, the height and angles of slopes of rocks massif, the width of working and transport site, the volume of mining preparatory work are considered as the main parameters of the development of a horizontal field. The height of the overburden bench is set according to the productivity of the excavators applied for their development so that the benches are advanced at the same speed. For this purpose the organization of production processes can be changed.

In the above circumstances, due to the decrease in demand for ore raw materials, the reengineering leads to a decline in the intensity of mining operations. In a glance of this decrease the volume of overburden is set according to clarifying the boundaries of the open pit field, balance reserves of ore and its quality. On accepted parameters, the overburden edge is formed, as well as the required capacity of the dumping front, taking into account the reduction of the volume of the dump to layout reduced volume of overburden rocks that will be developed. If necessary, for example, when the ready-totake reserve of ore raw materials is formed while developing overburden rock massif on three benches, organizing overburden and mining operations the upper bench in relation to the middle and lower benches are developed either in accelerated or in slow order. At the same time, organizational difficulties will be caused by the formation of developed space of required capacity. In some cases, the rock from the upper benches is placed in adjacent areas (in internal or external dumps), for which the technological scheme is reengineered and the parameters of the mining method are changed.

Changing the parameters of the mining scheme during open pit mine reengineering can cause the need of the use of additional equipment, for example, dragline for the formation of stable slopes of the benches or a reloader for the move of rock from the rotary excavator to the receiving bunker of face conveyor when changing the width of the working site.

Projects for the development of open pit fields at the Nikopol manganese-ore deposit provided for the achievement of high productivity of open pits for the mining of crude ore $(1,2-$ 1,6 million tonne/year for each open pit). Therefore, overburden massif was divided into benches in such a way that ensure the greatest advance of the front of the mining work with the help of more powerful bucket-wheel complexes. The upper bench is worked out according to the transport scheme using the rotor complex, and overburden is moved to the external or internal dump using conveyor transport. The middle (main) bench is operated according to the transport-dump scheme (bucket-wheel excavator and spreader) with the overburden rock moving to the internal dump. Above-ore bench is worked out according to non-transport scheme by dragline excavators with internal dumping. The use of belt conveyors increases the transport distance of overburden in a dump (up to 4-5 km), and, consequently, transport costs. The method of overburden and mining method of open pit field as a factor affecting the degree of filling the dump were not considered.

As mentioned above, the technology of mining operations to reduce the volume of extracted natural resources should be improved by the most complete placement of overburden in the stripped area of the open pit without the use of belt conveyors. In this way, the movement of the main volume of rocks into the dump at the shortest distance is achieved, which significantly reduces transport costs, and also contributes to increasing the area of restored land resources.

Using the above technological approaches in the view of the discrepancy of the capacity of applied complexes of mining operations at manganese open pits of the Pokrovsky MPE to the volume of market demand for manganese concentrate, the mining method of overburden massif under the combined system is improved [12, 13]. This improvement involves:

- cross movement of overburden rocks of the upper bench into a dump through direct handling without the use of conveyors;

- replacement of the upper bucket-wheel complex by a dragline that will advance the overburden to the intermediate 
bench for their further excavation by the bucket-wheel complex according to the transport-and-dump method;

- conducting mining operations at an open pit by a separate bench using an excavator such as direct shovel, followed by the transport of ore to an edge of an open pit by dump trucks;

- unloading of the dump massif and creation of a capacity in it to place the volume of overburden moved on the middle bench.

Based on the above approach, the technological scheme for developing overburden massif in the Chkalovsky-2 open pit by the transport-and-dump method and stripping method (Fig. 2) is proposed by the authors. In accordance with this scheme, the length of working front both in the mining and overburden operations, and dump bench, does not change, at the same time, the overburden equipment and the technology of the development of the top bench are changing.

An overburden massif with a capacity of up to $70 \mathrm{~m}$ is divided into three benches. The upper bench is the height of $17 \mathrm{~m}$, the middle one is $30 \mathrm{~m}$ and above-ore is $23 \mathrm{~m}$. The upper bench is moved to the slope of the bench of the bucketwheel excavator ERShR-5250 by the dragline ESh-15/90. For this purpose cut width of the bucket-wheel excavator ERShR5250 is increased by $25 \mathrm{~m}$. In combination with the reloader P-5250/120 the overburden spreader OShR-5000/190 is placed on the pre-dump, pilled by the dragline ESh-15/90 previously, which develops the above-ore bench. For the placement of overburden in the internal dump, walking excavator ESh-10/70 is used additionally [14]. It creates a trench receiver capacity by rocks stope from a cone story pilled by the spreader and moves it to the upper story of the dump. Under this scheme, an open mining cut is formed, which reduces the loss of ore raw material in the face. In general, according to the scheme, the re-excavation factor is $0.85 \mathrm{~m}^{3} / \mathrm{m}^{3}$.

The required volume of extracted ore $O_{o . r}$ is due to ore volume for concentrate production $O_{\text {o.p }}$ following to the market demand for this product. In general, the condition of $O_{o . r}$ $\geq O_{\text {o.p }}$ should be carried out. The demand for the enterprise's products significantly affects the productivity of its fixed assets, especially the active part, and thus determines the cost of production. Taking into account the small capacity of the ore bed (up to $2 \mathrm{~m}$ ), the defining element of the cost of manganese ore mining is the cost of overburden.

The cost of developing $1 \mathrm{~m}^{3}$ of rocks by a complex of technological equipment (bucket-wheel complex, a group of draglines or other equipment combined technologically) can be calculated on the sum of variable and fixed costs for servicing and maintenance of equipment units included to the complex, using the formula:

$$
C_{d . r}=\frac{C_{f}}{N_{m} n_{s h} Q_{o}}+\frac{C_{v . m}}{Q_{e f}}+\frac{C_{v . c} T_{s h}}{Q_{o}}, \mathrm{UAH} / \mathrm{m}^{3},
$$

where $C_{f}$ - fixed costs for depreciation of the equipment complex, payment for set capacity, support materials, etc., UAH/ month; $N_{m}, n_{s h}$ - the number of working days per month and shifts per day; $Q_{o}, Q_{e f}$ - the productivity of the equipment complex, respectively, operational, $\mathrm{m}^{3} /$ shift; and effective, $\mathrm{m}^{3} / \mathrm{h}$; $C_{v, m}$ - variable costs per 1 machine-hour of operating equipment complex (remuneration of labor for the crew of main workers, expenses for repair parts, lubricants, electric power, etc.), UAH; $C_{v . c}$ - variable costs for 1 hour of the calendar time of the crew of service workers (ropes, assets of low unit value,

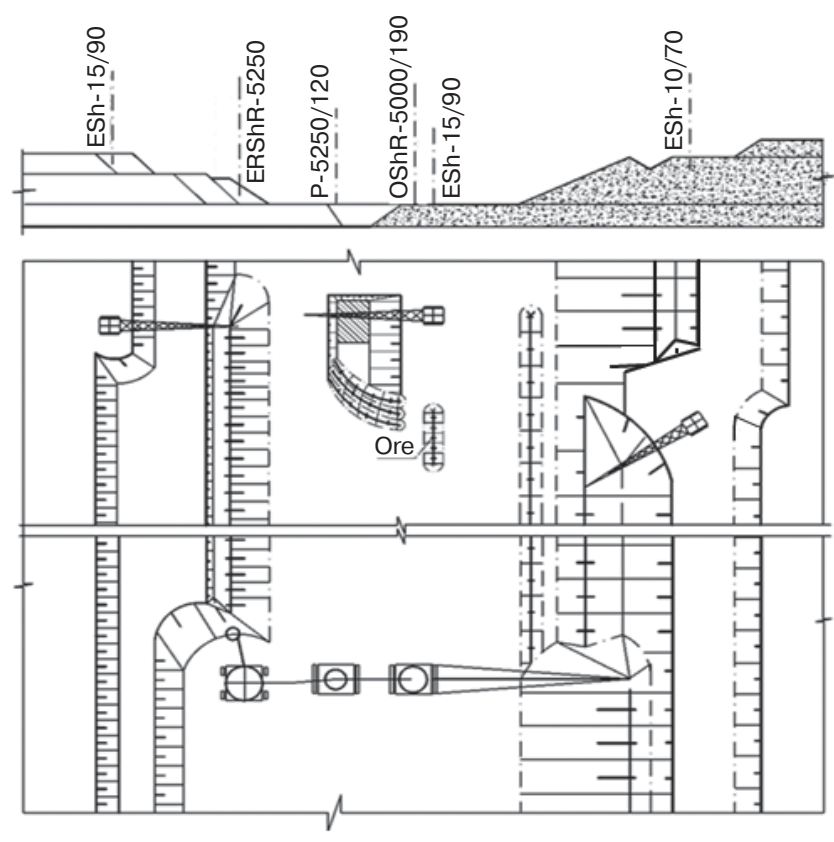

Fig. 2. Improved technological scheme of overburden works at the Chkalovsky-2 open pit

overalls, tools, devices, etc.), UAH; $T_{s h}$ - duration of working shift, h.

In general, determined by market demand the volume $O_{\text {o.p }}$ of ore extraction is ensured by advancing $A_{f . w}$ of working front of overburden and ore benches, which should satisfy the condition:

$$
A_{f . w} \geq \frac{O_{o . p}}{m_{o} \gamma_{o} L_{o . o} k_{e . r}}, \mathrm{~m} / \text { year, }
$$

where $m_{o}$ - the thickness of ore seam, $m ; \gamma_{o}$ - the density of manganese ore, $\mathrm{t} / \mathrm{m}^{3} ; L_{o . o}$ - the length of the working front of ore bench, $\mathrm{m} ; k_{\text {e.r }}$ - extraction ratio of ore reserves in the face, the share of units.

On the assumption of the advance of working front of overburden and mining operations according to the formula (2), the productivity of the equipment complex for each overburden bench should be equal to:

$$
Q_{p}=A_{f . w} H_{o . f} L_{o . f}, \mathrm{~m}^{3} / \text { year, }
$$

where $H_{o . f}, L_{o . f}$ - the height and the length of working front of overburden bench, respectively, $\mathrm{m}$.

Formula (3) takes into account the additional volume of overburden, which is excavated by the dragline from the upper bench to the slope of the middle bench. Determined according to the formula (3), the productivity of equipment on one or another bench is used in calculating the cost of overburden by the formula (1). The feasibility of introducing a certain mining technology is estimated at the operating cycle level, based on the gross profit, which is formed as the difference between sales proceeds and production costs. It should be noted here that new capital investments for the implementation of the proposed technological scheme are not needed. The equipment needed for this scheme is in the Chkalovsky-2 open pit and in other open pits of the Pokrovsky MPE. In this case, the increase in profit due to the reengineering of the technological scheme of overburden works according to the proposed option will be calculated by the formula: 
$\Delta P_{r}=P_{g . a}-P_{g . p}, \mathrm{UAH} /$ year,

where $P_{\text {g.a }}, P_{\text {g.p }}$ - the gross profit, which can be earned according to proposed and current schemes of mining works at the open pit, respectively.

Consequently, the above mining method for the development of manganese bed can lead to a reduction in the cost of overburden, resulting in reducing of production costs by the value:

$$
\Delta P_{r}=\left(C_{p . a}-C_{p . p}\right) O_{o . p}, \text { UAH/year, }
$$

where $C_{p . a}, C_{p . p}$ - the cost of the development of overburden according to the current and proposed technologies of overburden works, respectively, $\mathrm{UAH} / \mathrm{m}^{3} ; \mathrm{O}_{\text {o.p }}$ - the volume of overburden according to the proposed technology, $\mathrm{m}^{3} /$ year.

The efficiency of reengineering of mining method of overburden benches in the Chkalovsky-2 open pit operating currently is determined. As mentioned above, the upper bench is suggested to combine with the middle one. On the upper bench, the bucket-wheel complex, belt conveyors and spreader are completely dismantled, and dragline is used for moving overburden rocks from this bench. The whole combined bench is moved to the internal dump by a bucket-wheel excavator according to the transport-and-dump method. Since reengineering is carried out in the open pit which is operating, the feasibility of conducting it is checked on the basis of working regimes and valuations of service of the mining-andtransport equipment in open pits of the Pokrovsky MPE.

Calculations based on the above formulas (1) - (5) show (See Table) that in the Chkalovsky-2 open pit the total cost of overburden works of 340-1030 thousand tons per year productivity in ore are respectively, 97422.5-231267.6 thousand UAH per year and 82222.5-224139.6 thousand UAH per year according to the current and the offered technological schemes. Hence, conducting reengineering of the mining method of overburden works, the cost of their performing can be reduced by $15200-7128$ thousand UAH (by $18-3 \%$ ). At the same time, in case of the increase in the annual volume of ore mining to 1030 thousand tons, the economic effect of the combination of upper and middle benches and their movement into the internal dump according to the transport-anddump method in the amount of 7128 thousand UAH is not significant in comparison with the previous effect, in order to substantiate the expediency of such a reengineering.

Finally, it should be noted that the production capacity of the open pit should be reduced not by falling down the productivity of complexes, but by putting units of its equipment out of operations. Decrease in productivity by $20-25 \%$ allows taking outdated equipment out of service from open pits and plants, to release workers gradually and to create a reserve of capacity, which is needed for the stable operating of mining and processing enterprise in the market economy. Substantiation of working regime in the conditions of changing demand for the products is important and topical issue, since it determines the possibilities of making effective decisions on the temporary suspension of certain technological workshops of the enterprise timely.

\section{Conclusions}

1. Reengineering of the technological complex of the development of the deposit in order to reduce the cost of mining ore raw materials should be based on reducing the production capacity of the complex, which is not needed due to reduced demand for raw materials. The methodical approach
Indicators of the proposed technological scheme of overburden woks at the Chkalovsky-2 open pit

\begin{tabular}{|c|c|c|c|}
\hline Indicators & \begin{tabular}{|c|} 
Above- \\
ore bench
\end{tabular} & $\begin{array}{l}\text { Middle } \\
\text { bench }\end{array}$ & $\begin{array}{l}\text { Upper } \\
\text { bench }\end{array}$ \\
\hline \multicolumn{4}{|c|}{ With the productivity of the open pit in ore, 340 ktonnes per year } \\
\hline $\begin{array}{l}\text { 1. The productivity of the } \\
\text { open pit by the overburden, } \\
\text { thousand } \mathrm{m}^{3} / \text { year }\end{array}$ & 1725 & $2250+1275$ & 1275 \\
\hline 2. Cost of overburden, $\mathrm{UAH} / \mathrm{m}^{3}$ & 10.1 & 22.0 & 12 \\
\hline $\begin{array}{l}\text { 3. Average weighted cost of } \\
\text { overburden, } \mathrm{UAH} / \mathrm{m}^{3}\end{array}$ & \multicolumn{3}{|c|}{15.66} \\
\hline $\begin{array}{l}\text { 4. Costs for the development of } \\
\text { the bench, thousand } \mathrm{UAH} / \text { year }\end{array}$ & 17422.5 & 49500 & 15300 \\
\hline $\begin{array}{l}\text { 5. Annual costs on overburden, } \\
\text { thousand UAH }\end{array}$ & 17422.5 & \multicolumn{2}{|c|}{64800} \\
\hline $\begin{array}{l}\text { 6. Economic effect, thousand } \\
\text { UAH/year }\end{array}$ & \multicolumn{3}{|c|}{15200} \\
\hline \multicolumn{4}{|c|}{ With the productivity of the open pit in ore, 1030 ktonnes per year } \\
\hline $\begin{array}{l}\text { 7. Productivity of the open pit } \\
\text { by the overburden, thousand } \\
\mathrm{m}^{3} / \text { year }\end{array}$ & 5221 & $6810+3859$ & 3859 \\
\hline 8. Cost of overburden, $\mathrm{UAH} / \mathrm{m}^{3}$ & 9.6 & 20 & 9.8 \\
\hline $\begin{array}{l}\text { 9. Average weighted cost of } \\
\text { overburden, } \mathrm{UAH} / \mathrm{m}^{3}\end{array}$ & \multicolumn{3}{|c|}{14.1} \\
\hline $\begin{array}{l}\text { 10. Costs for the development of } \\
\text { the bench, thousand UAH/year }\end{array}$ & 50121.6 & 136200 & 37818 \\
\hline $\begin{array}{l}\text { 11. Annual costs on } \\
\text { overburden, thousand UAH }\end{array}$ & 50121.6 & \multicolumn{2}{|c|}{174018} \\
\hline $\begin{array}{l}\text { 12. Economic effect, thousand } \\
\text { UAH/year }\end{array}$ & \multicolumn{3}{|c|}{7128} \\
\hline
\end{tabular}

has been determined for making a decision on the feasibility of a complex reengineering, which ensures acceptable production costs and a volume of production in accordance with market demand.

2. Under the condition of low capacity of manganeseore bed (up to $2 \mathrm{~m}$ ), the feasibility of reengineering of mining works' complex of working manganese open pit is determined according to the cost of overburden developing of $1 \mathrm{~m}^{3}$ for the sum of variables and fixed costs on servicing and maintenance of units of equipment included to the complex. Thus, for each bench the influence of excavators' productivity on the cost of overburden works is taken into account.

3. As for overburden massif of manganese open pit, developing of the upper bench with the use of conveyor transport is not recommended. For this purpose, it is proposed to move the upper bench by a dragline under the slope of the middle bench and overburden rocks from both of the combined benches in the internal dump by the bucket-wheel complex under the transport-and-dump method. The placement of overburden in the trench capacity formed by dragline in the internal dump allows reducing the volume of re-excavation. The capacity of the technological complex is decreasing that leads to reducing the cost of mined ore.

4. For the Chkalovsky-2 open pit costs of overburden works are determined under the current and proposed technological schemes. In the case of reengineering under the productivity of the open pit of 340-1030 ktonnes per year are respectively, 97422.5-231267.6 thousand UAH per year and 82222.5-224139.6 thousand UAH per year according to the current and proposed technological schemes. 
5. Now some manganese open pits of the Pokrovsky MPE are under cleaning-up of ore reserves. In this respect researches of a reengineering of a technological scheme of mining operations under cleaning-up of pit area are needed. In this aspect, not enough attention is still being paid to the solution of issues related to the technology for cleaning-up of deposit and the closure of open pits, as well as the production costs for the improvement of their surface.

References

1. Available at: https://www.metaltorg.ru/n/9A9446 (accessed: 23.03.2020).

2. Available at: https://ukrmet.dp.ua/2016/11/18/ukraina-vyanvare-oktyabre-2016-goda-import-margancevoj-rudysostavil-8895-mln.html (accessed: 23.03.2020).

3. Sadykov A. A. Substantiation of organizational and technical soulitons and strategies for the reconstruction of the career of Kaliningrad Amber Combine. GIAB. 2016. No.11. pp. 418-425.

4. Lutsenko S. A. Determination of an open pit performance by ore for various methods of mining operations development. Collection of scientific works of Dnipro University of Technology. 2017. Vol. 52. pp. 87-92.

5. Serdyukov A. L., Abrosimova G. G., Kudryashov V. S., Levin Ye. L. Justification of dynamic boundaries and output of deep open pits versus changing market scenarios for mine design and scheduling. GIAB. 2015. Special issue 56. pp. 310-318.
6. Shapar A. H., Yemets N. A., Kopach P. I. et al. Innovative technologies for mining region subject to resource restriction. Ekologiya i promyshlennost. 2015. No. 2. pp. 19-25.

7. Temchenko O. A. Determination of the rational production capacity of ore processing enterprises to enhance their competitive positions. Editors of scientific bulletin of Mukachevo State university. Ser. Economics. 2015. Iss. 2(4). Part 1. pp. 128-135.

8. Cherep A., Pilova D. Technological Ensuring of Production Competitiveness of Mining and Processing Enterprises. Advanced Engineering Forum. 2017. Vol. 25. pp.166-170.

9. Samavatia M., Essamb D., Nehring M., Sarkerb R. A new methodology for the open-pit mine production scheduling problem. Omega. 2017. Vol. 81. DOI: 10.1016/j.omega.2017.10.008

10. Morteza P., Morteza O. A simulation-based framework for estimating probable open-pit mine closure time and cost. Journal of Cleaner Production. 2017. Vol.167. pp. 337-345.

11. Kuter N. Reclamation of Degraded Landscapes due to Opencast Mining. Advancesin Landscape Architecture. Ed. by Murat Özyavuz. 2013. DOI: 10.5772/55796

12. Vagonova O., Mormul T., Zakharchenko Yu., Romaniuk N., Kasianenko L. Topical problems concerning both methods and economy to develop mineral deposits. Mining of Mineral Deposits. 2018. Vol. 12(4). pp. 82-89.

13. Cherep A. Yu. Improvement of combined development system of overburden rock in variable demand for ore raw material. Scientific reports on resource. 2011. Iss. 1. pp. 167-171.

UDK 621.386:622

L. A. VAISBERG ${ }^{1}$, Research Manager, Professor, Doctor of Engineering Sciences, Academician of the Russian Academy of Sciences

E. E. KAMENEVA², Senior Researcher, Associate Professor, Candidate of Engineering Sciences, elena.kameneva@mail.ru

${ }^{1}$ Mekhanobr-Tekhnika, Saint Petersburg, Russia

2 Petrozavodsk State University, Petrozavodsk, Russia

\section{X-RAY COMPUTED MICROTOMOGRAPHY AS THE BASIS FOR MINERAL PROCESSING IMPROVEMENT : REVIEW}

\section{Introduction}

The development of advanced resource-saving technologies for mineral processing requires a comprehensive study into material composition of minerals, their structural features and behavior of mineral phases in disintegration and concentration. In this regard, there is a need to improve the methodological approaches to the study of ores and rocks and to apply advanced instrumental diagnostic methods in the mineral engineering.

X-ray computed microtomography is one of the promising introscopic methods for studying mineral raw materials, which has recently been successfully used to study ores, rocks, coal, mining and processing waste, composites and other materials.
This article provides a brief review of the application of the X-ray computer microtomography in the studies of mineral raw materials, as well as the relevant generalized results of the authors'own research. It is noted that X-ray computed microtomography is one of the promising introscopic methods for studying mineral raw materials, which has recently been successfully used in researches of ores, rocks, coal, mining and processing waste, composites and other materials. The advantages of tomography, as compared to other $x$-ray and optical methods, consist in its efficiency and high information content at minimized human factor.

Along with the growing popularity and relevance of the method, the number of problems to be solved using $x$-ray microtomography is also increasing. In particular, a very urgent problem is to study dynamics of change in internal structure of rocks exposed to various force fields (compression, tension, temperature and other effects) in practical geotechnology and mineral processing. Being a non-destructive research method, X-ray computed microtomography has a number of undeniable advantages in studying processes of deformation and fracture of ores and rocks as it allows examining pore space structure of rock samples without destroying them. At the same time, the review of relevant publications demonstrates that in each case, the tomographic characteristics of separate (or single) samples are studied and described depending on a specific objective. At the moment, no generalized dependencies have been identified to describe the relationship between the structures of pore space and the physical and mechanical properties of rocks. Computed tomography enables quantitative characterization of the pore space structure with regard to the physical and mechanical properties of rocks, which provides the grounds for substantiating energy-efficient crushing methods with allowance for textural and structural features of ores and rocks.

Key words: computed X-ray microtomography, ores, rocks, pore space. DOI: $10.17580 / \mathrm{em} .2020 .01 .09$ 